\title{
Specialist winter milk production from pasture at No. 1 dairy farm, Massey University
}

\author{
G.A. Lynch \\ Dairy Farms Supervisor, \\ Massey University
}

\begin{abstract}
Premiums offered by some dairy companies for milk produced in the winter months led No. 1 Dairy Farm at Massey University to explore and instigate alternative options for winter milk production. Options were evaluated in a number of computer models, using information gathered from the farm. Transition to $100 \%$ autumn calving began in November 1987. 100\% autumn calving improved gross margin from the enterprise and provided opportunities to further research problems inherent to winter milk production. Calving cows in autumn coincides with declining pasture growth. Shortfalls between pasture production and stock requirements in early lactation are filled using conserved pasture. The losses and inefficiencies associated with conserving feed are largely responsible for the lower stocking rate carried and lower total production from the farm. Fertiliser nitrogen and winter-active pasture species assume importance in the feeding strategy on the farm.
\end{abstract}

Keywords winter milk production, grassland management

\section{N T RO D U C T I O N}

Changes in 1987 to the legislation on the production and supply of milk to the New Zealand domestic market, and overseas marketing opportunities for specialist milk products, resulted in some dairy companies offering premium for milk produced in the winter months (Anon. 1987). To profit from these premiums some dairy farmers have altered their management systems to calve all or part of their herd in autumn. Past experience at No. 1 Dairy Farm with a split autumn/spring calving pattern had highlighted some problems associated with autumn calving herds, although little research data were available to provide satisfactory answers to these problems.

This paper reports on initiatives taken at No. 1 Dairy Farm to establish a winter milk production system and discuss some of the implications of adopting such a system for grassland management.

\section{BACK GROUND}

Massey University's No. 1 Dairy Farm lies on the eastern bank of the Manawatu River and consists of
110 ha of river accretion soils of the Manawatu and Rangitikei silt loam series. These soils are of high natural fertility, free draining and subject to summer drought and infrequent flooding.

For many years the farm was operated as a commercial town milk farm meeting a daily quota of between 1200 and 1400 litres. Quota was met by using a split-herd calving pattern with approximately 90 cows calving from 20 March and 170 cows calving from 7 August. Calving spread of each herd was 7-9 weeks with intensive animal health recording and management to retain these calving patterns (Hislop 1987).

The farm is intensively monitored to provide data for management decisions and to assist teaching programmes. Pastures are measured fortnightly with a rising plate meter (Earle \& McGowan 1979), the herd is tested for milk and milk component yield monthly, and stock liveweights are measured monthly.

Monitoring stock and farm performance evinced poorer performance of both individual animals and the farm when compared with similar seasonal supply farms. For example, daily milk production patterns for cows in the autumn herd peaked at much lower levels than those for the spring herd (Figure 1). In most years, however, a longer lactation from the autumn cows compensated, so that production per cow from each herd was similar. Reproductive performance of cows in each herd

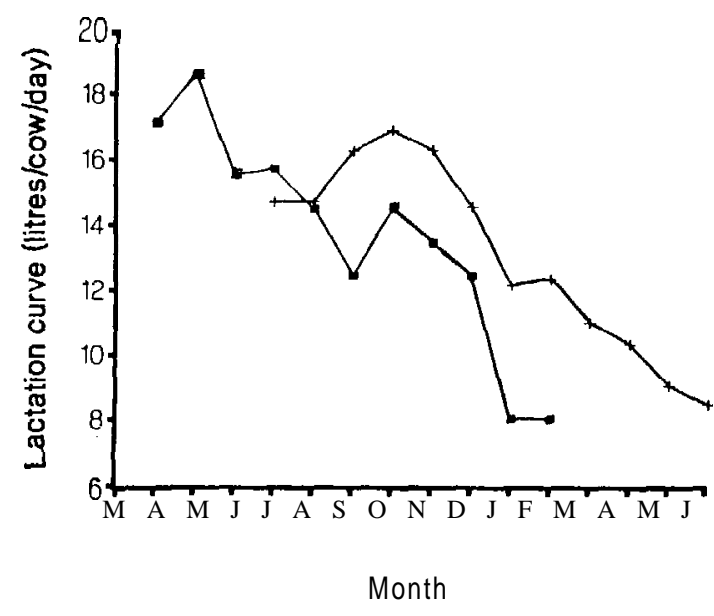

Figure 1 Lactation curve, autumn and spring calving cows 1988189.

$x+x$ spring

autumn 
showed similar trends, as reported by Shrestha ( 1978) and Wiseman ( 1984), in that performance of autumn-calving cows was lower than that of springcalving cows.

Pasture varieties had been evaluated under a town milk production system for a number of years in cooperation with DSIR Grasslands. This had led to the establishment and management of significant areas on non-traditional pasture types as well as pastures based on varieties of perennial ryegrass. Of particular significance was 32 ha of pastures based on 'Grasslands Matua' prairie grass.

With this background and the increasing need for more information on winter milk production systems, initiatives were taken in November 1987 to change the management of No. 1 Dairy Farm from a town milk supply system to one primarily producing winter milk. Commercial objectives continued to be met by a special quota arrangement with Manawatu Co-op Dairy Co. Ltd; teaching opportunities were increased; and problems inherent to winter milk production could be more fully researched.

\section{Planning}

A winter milk production system was evaluated initially with a simple spreadsheet feed budgeting model (Gray \& Lockhart 1985). Subsequently, more complex feed budgeting and gross margin models were used (Brookes 1988; Baldwin \& Anderson 1989).

In all modelling exercises, a basic philosophy was adhered to of maximising gross margin from a permanent pasture-based system using the resources of the farm. The farm supervisor and manager set minimum and maximum parameters for feeding levels, average pasture covers, pasture growth rate, liveweight gain, cow condition and production level, based on past experience and historical records from the monitoring programme at No. 1 Dairy Farm. Financial parameters were taken from past farm working accounts. Product prices were based on the proposed payout system of the New Zealand Cooperative Dairy Co Ltd (premium of $\$ 5 / \mathrm{kg}$ milkfat above current milkfat prices for milk produced in May, June and July (Anon. 1987)) and the town milk payment system ruling at the time for the Manawatu Co-op Dairy Co Ltd.

\section{RESULTS OF MODELLING EXERCISES}

A number of management options were presented for maximising gross margin in a winter milk production system. A system with $100 \%$ autumn calving was adopted as it was felt this presented greater research and teaching opportunities.

The main results of $100 \%$ autumn calving were:

(1) Stocking rate Would decline from 260 cows ( 2.3 cows/ha) to between 200 and 240 cows (1.82$2.18 \mathrm{cows} / \mathrm{ha}$
(2) Production per cow Diluting maintenance requirements by increasing per cow production would increase both total production and gross margin.

(3) Calving date $\mathrm{A}$ calving date between 1 March and 30 April would be most appropriate, depending on start date of premium payments for milk.

(4) Drying off date A lactation length as close to 300 days as possible would maximise both production and gross margin.

(5) Supplements used and made Pasture production pattern and stock requirement patterns are shown in Figure 2. An autumn calving system would be' 'out of phase' with pasture production patterns. To meet winter shortfalls and utilise pasture growth over an annual cycle, approximately 600 tonnes of silage would be made compared with 400 tonnes under the town milk system. Furthermore, the high losses associated with manufacture and storage of supplements (Thomson 1985 ) meant that it would be preferable to use cow condition rather than supplements as much as possible to provide energy for milk production at times when stock requirements exceed pasture growth rates. Thus, managing stock to have them calving at a high condition score (C.S. 6) would be preferable.

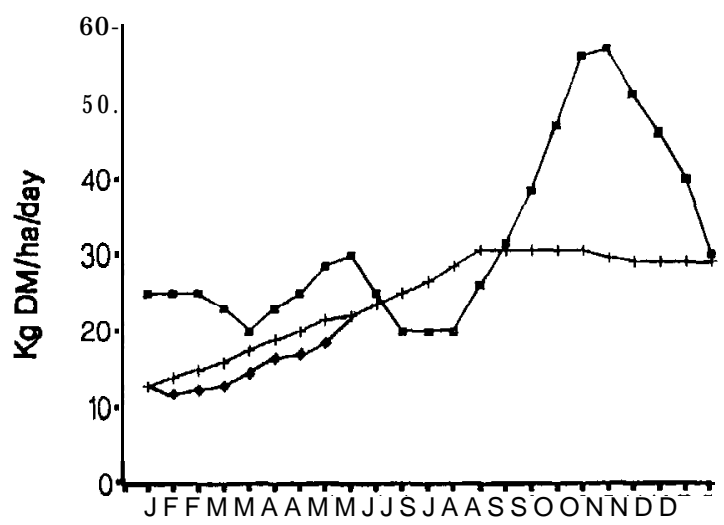

Month

Figure 2 Predicted annual pasture production and anima requirement patterns.

$\longrightarrow$ pasture growth rate

$\longleftrightarrow$ stock requirements (200 autumn calving cows) supplemented with summer green feed crop

(6) Total production Mainly as a result of the inefficiencies associated with pasture conservation, total production from the farm would decline from approximately 900000 to 820000 litres. Gross margin would improve substantially, however, with the increase in the proportion of total milk going to winter domestic market. 


\section{IMPLEMENTATION OF RESULTS}

Implementation of the winter milk production system was approved in November 1987. At this time half the spring herd had been mated and consequently full enactment will take at least two seasons. Seventy-five spring calving cows were carried over for mating in the winter of 1988 , and milked through until November 1988. The remainder of the spring herd ( 100 cows) calved in August 1988. In autumn 1989, 170 cows were calved and a further 32 spring cows were carried over for mating in June 1989. We expect that 190 200 cows will be calved in autumn 1990.

Figure 3 shows average pasture cover on the farm in the last 14 months. During spring, a flood on 30 September which covered $70 \%$ of the farm for 2 days meant recovery of low pasture covers at the end of August was delayed 2-3 weeks. 220 tonnes of silage was harvested off 17 ha on 10 November and a further 180 tonnes off 12 ha on 20 December. Dry conditions in November and December meant the amount of pasture conserved was lower than required for the following winter, and consequently 6 ha maize was sown for silage in late November. Adequate pasture cover and silage appeared to be on hand at the beginning of calving on 10 March, although milking the spring herd at this time depleted this reserve faster than management desired. Four tonnes of urea were applied in late March

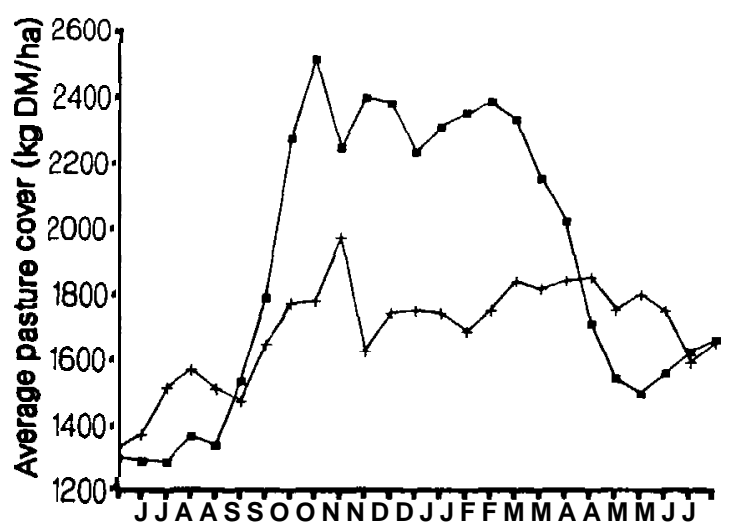

Month

Figure 3 Average pasture cover over No. 1 Dairy Farm. $\longrightarrow$ predicted

actual 1988/89

Over the 1989 winter, feed reserves were utilised faster than modelled and cow production was lower than expected. Wet conditions in July affected utilisation and aggravated the results, although the assumptions used in the models must be questioned and some of these relationships more fully researched.
Very low average pasture cover in late July 1989 (1300 kg DM/ha) meant a further 5 tonnes urea was applied in early August. Recovery of pastures over August and September is likely to be slow.

\section{DISCUSSION}

The development of No. 1 Dairy Farm to $100 \%$ autumn calving is not yet complete. The 1990/91 season will be the first season in which all cows milked will be fresh autumn cows. Calving cows at a time when pasture growth is declining poses a number of management problems. Feed allocation becomes a priority to ensure freshly calved cows are fed adequately, and to avoid prejudicing both pasture and animal production in late winter. Feed budgeting is essential, although in hindsight the feed budgets prepared in winter 1989 did not adequately reflect the true situation. Relationships betwen feed offered and production level require further definition. Losses through wastage are probably higher than expected and pasture quality may be lower than that of spring pastures when fed to cows at comparable stages of lactation.

The use of supplements becomes a very important issue. Adequate quantities of high quality supplements are needed to till feed shortfalls in winter and harvest surpluses arise in spring and early summer owing to lowered effective stocking rate. Because silage is harvested and stored for feeding to lactating animals, harvesting at the optimum growth stage for quality and quantity is important. Silage is needed in winter to make up one third to one half of milking cow rations. Adequate stocks must also be carried to overcome the risks associated with variable late summer and autumn pasture growth.

The use of fertiliser nitrogen to enhance pasture growth during winter and early spring also becomes an issue. Although responses are likely to be lower at these times than with spring applications, they provide useful feed for a product with high value, and thus are more likely to be economic.

The response of lactating cows to grain-based high quality supplements in winter is very often substantial. The use of these supplements should not be discounted, particularly when carryover effects on reproductive performance of the cows are taken into account (Wilson 1989).

Large areas of No. 1 Dairy Farm are sown in Matua prairie grass based pastures. This has enabled these pastures to be compared informally with perennial ryegrass pastures. When compared with ryegrass, the earlier growth characteristics of prairie grass at the end of drought and winter are important in the overall feeding strategy. In autumn and late winter, great reliance is placed on prairie grass pastures to feed the herd before other pastures become active. The use of other winter-active species such as phalaris is being investigated. The 
selection and development of winter-active legumes suitable for New Zealand conditions could enhance the feeding value of winter pastures and is the subject of present research.

\section{CONCLUSIONS}

No. 1 Dairy Farm is establishing a winter milk production unit in response to changes in the pricing and arrangements for winter milk and the need for information on winter milk production.

Calving cows in autumn means the increasing feed requirement of the herd coincides with declining pasture growth, thus putting greater emphasis on conserved feed and allocation of feed reserves. The losses and inefficiencies of conserving feed affect the stocking rate that can be carried and total production from the farm. Use of fertiliser nitrogen and winter-active pasture species contribute to filling feed gaps in the winter months, and their use at No. 1 Dairy Farm is of significance particularly in late autumn and late winter/early spring.

Despite the progress at No. 1 Dairy Farm in the 1989 season, it is increasingly obvious relationships used in predictive models may not be appropriate for winter milk production systems. Concurrent research projects underway at No. 1 Dairy Farm will provide further information which will enable more accurate predictions of production in the future.

Since the inception of the winter milk project at No. 1 Dairy Farm, further developments have occurred in pricing policies for winter milk. Price structures do affect the optimum calving patterns for herds producing winter milk, and a $100 \%$ autumn calving herd may not necessarily be the best option. Split-herd calving patterns provide greater flexibility of management, reduce the need for conservation of pasture surpluses and spread risk. However, 100\% autumn calving, although creating problems, can be a viable and profitable venture.

\section{REFERENCES}

Anon. 1987. Factory farmers contract to give winter milk. Dairy Export\& 63: (October 1987) 4:24.

Baldwin, G.W.: Anderson, F.M. 1989. A case studv analysis using linear programming of the winter milk production option on a New Zealand dairy farm. Department of Agricultural and Horticultural Svstems Management, Massey University. (In press).

Brookes, I. 1988. Dairy cow models. Agripute. The Computer Magazine for Farmers, Consultants and Vets 1:3: 34-35.

Earle. D.F.: McGowan. A.A. 1979. Evaluation and calibration of an Automated rising plate meter for estimating dry matter yield of pasture. Australian Journal of Experimental Agriculture and Animal Husbandry 19: 337-343.

Gray, D.I.; Lockhard, J.C. 1985. Student guide to Multiplan worksheets. Department of Agricultural and Horticultural Systems Management, Massey University.

Hislop, D. 1987. Monitoring and control of health and fertility on a town supply dairy farm. 1987 Dairy Farming Annual. pp 47-5 1, Massey University.

Shrestha, S.L. 1984. Reproductive efficiency in town supply herds. Massey Unversity.

Wiseman, P.R. 1984. Dairy cattle reproduction: Management in the town supply herd and use of records. Proceedings Dairy Cattle Society New Zealand Veterinarian Association Seminar: 122-1 31 .

Thomson, N.A. 1985. Pasture conservation and dairy production. 1985 Dairyfarming Annual, pp. 45-43, Massey University.

Wilson, G.F. 1989. Winter milk production and fertility problems in a pasture-based dairy system. Proceedings World Conference on Production Disease in Farm Animals (In Press). 